PAOLA PiETRANDREa (Rome)

KATERINA STATHI (Berlin)

\title{
What counts as an evidential unit? The case of evidential complex constructions in Italian and Modern Greek
}

The evidential meaning traditionally attributed to modal auxiliaries is conveyed in Italian and Greek by complex constructions clustering both modal and aspectual features. The evidential reading of Italian and Greek modal auxiliaries, indeed, is only licenced when the modals take as complements stative, progressive, habitual or resultative subordinates. A feature of aspectual incompleteness of the subordinate is therefore necessary in order to obtain an evidential reading of the auxiliary. This leads us to propose the entire construction combining the auxiliary, the subordinate and the specification of its aspectual values be taken as an entry of the database of evidential units.

\section{Introduction}

Designing a database of evidential units requires taking a number of theoretical decisions at the outset. The most basic one concerns the very definition of what should count as an evidential unit. This entails at least three different major theoretical questions: (1) What does "evidential" mean? How do we define evidentiality? How do we classify evidential values? A number of papers in this volume provide an answer to this question. (2) How do we distinguish between units that are intrinsically evidential and units that are only contextually evidential? In other words, how do we distinguish between units that semantically code evidentiality and units that pragmatically implicate (through conversational implicature or explicature) evidentiality? This is one of the central questions addressed in BOYE (this volume). Finally, one may ask: (3) What is the formal complexity of an evidential unit? At what level of analysis can we detect the encoding of evidential meaning? Is evidentiality encoded in morphemes, in lexemes, or should we consider evidentiality as encoded in complex constructions? Can we take these constructions as basic units of our database?

In this paper we will focus on the third issue. We will claim that evidentiality is coded by constructions rather than by single items. We will claim, in particular, that the evidential meaning traditionally attributed to modal auxiliaries is conveyed, indeed, at least in Greek and in Italian, by complex constructions clustering both modal and aspectual features.

\section{Modal auxiliaries}

In order to show that evidential meanings are better regarded as conveyed by entire constructions rather than by single items, let us examine the case of the modal auxiliaries in two not closely related languages, Italian and Modern Greek. Both languages are commonly regarded as having epistemic-evidential modal auxiliaries (cf. SQUARTINI 2004 and PIETRANDREA 2005 for Italian, ClAIRIS \& BABINIOTIS 1999 for Greek). Italian has four evidential forms of modal auxiliaries: the indicative and the conditional forms of the modal potere ('can'), the indicative and the conditional forms of the modal dovere ('must'). Similarly, Greek uses the third person form (bori) of the modal verb boró ('can') and the third person (impersonal) modal prépi ('must'). Both verbs are followed by a clause introduced 
by the subordinate marker $n a .^{1}$ In what follows, we will focus on the indicative form of the modal auxiliary dovere (which will conventionally be labelled DEVE, using the third person form of the present as a label for the entire inflection) for Italian and, for Greek, on its counterpart, the modal verb prépi (+ na-clause).

The modal DEVE followed by an infinitive complement is usually used to express dynamic or deontic modality. It can also express direct, inferential, perceptual evidentiality (PIETRANDREA 2004, 2005; SQUARTINI, 2004) under c e rt a in circumstances. Similarly, the modal prepi followed by a dependent finite clause introduced by $n a$ has a basic deontic meaning; under certain circumstances it can also acquire evidential (inferential) meaning.

We will show that the circumstances under which the two modals acquire evidential meaning are easily calculable: the aspectual value of the subordinate clause determines the evidential or deontic interpretation of the verb. It could be claimed, therefore, that the evidential meaning is not expressed by the modal verb per se, rather by complex periphrastic constructions combining the modal verb, the infinitive/dependent clause and specific aspectual values of the dependent verb.

\subsection{DEVE + statives}

Examples from (1) through (4) show that the modal DEVE can receive an evidential interpretation only if it is followed by a stative infinitive. When DEVE takes an infinitive referring to other actional classes (activities, accomplishments, achievements) as complement, it can only have a deontic interpretation.

STATES

[+EVIDENTIAL -DEONTIC]

(1) Gianni deve essere stanco / avere quindici anni. 'Gianni must be tired / be 15.'

\section{ACTIVITIES}

\section{[-EVIDENTIAL +DEONTIC]}

(2) Gianni deve camminare / scrivere. 'Gianni must walk / write.'

\section{ACCOMPLISHMENTS}

(3) Gianni deve digerire / dimagrire.

'Gianni must digest / get thinner.'

\section{ACHIEVEMENTS}

(4) Gianni deve saltare / partire.

\section{[-EVIDENTIAL +DEONTIC]}

'Gianni must jump / leave.'

\subsection{DEVE + progressives}

It should be said, however, that the construction made up of DEVE and a nonstative infinitive can receive an evidential interpretation provided that the subordinate infinitive displays certain aspectual values. For example, if DEVE is

\footnotetext{
${ }^{1}$ There is no infinitive in Modern Greek.
} 
followed by a non-stative infinitive in the progressive form, it can receive an evidential interpretation. This is the case with the activity predicate camminare ('to walk'), the accomplishment predicate digerire ('to digest'), and the achievement predicate saltare ('to jump') in (5):

(5) Deve stare camminando / digerendo / saltando. 'He must be walking / digesting / jumping.'

[+EVIDENTIAL-DEONTIC]

\subsection{DEVE + habituals}

Similarly, DEVE can receive an evidential interpretation when it takes infinitives of non-stative predicates having an habitual meaning as complement. This is shown in the examples from (6) to (8):

(6) Deve camminare ogni giorno, se è così in forma. '(S)he must walk every day to be so fit'

[+EVIDENTIAL -DEONTIC]

(7) Deve dimagrire senza problemi, visto che si permette di mangiare tutto quel cioccolato [+EVIDENTIAL -DEONTIC].

'(S)he must get easily slim, to eat so much chocolate'

(8) Deve partire molto spesso, a causa del suo lavoro.

[+EVIDENTIAL -DEONTIC] '(S)he must leave very often, due to her / his job'

\subsection{DEVE + resultatives}

DEVE preferentially receives an evidential interpretation when it takes infinitives of non-stative predicates having a resultative aspect as complement, i.e., marking the enduring, at the reference moment, of the results of an event which took place previously. For example:

(9) Deve aver camminato, aver digerito, aver saltato. '(S)he must have walked, have digested, have jumped'

\subsection{Summary}

All in all, the Italian modal DEVE receives an evidential interpretation when it is followed by stative, progressive, habitual and resultative infinitives. This phenomenon is not isolated: before attempting an interpretation, we will show that the Greek modal prépi na behaves, apart from some exceptions, in a similar way.

\section{Prépi in Modern Greek}

Before demonstrating the aspectual restrictions that hold for an evidential interpretation, an explication of the paradigm will be given.

Greek makes a fundamental distinction between imperfective and perfective aspect. The aspectual distinction interacts with tense (non-past and past): it is possible, therefore, to have both a past and a present imperfective and both a past 
and a present perfective. ${ }^{2}$ Most Greek verbs have both imperfective and perfective stems, ${ }^{3}$ which are used to form different sets of forms (HOLTON et al. 1997: 109ff.). Table 1 shows the interaction of aspect (imperfective/perfective) with tense (nonpast/past) for the verb yráfo 'write'.

\begin{tabular}{||l|l|l||}
\hline & IMPERFECTIVE & PERFECTIVE \\
\hline Non-past & $\gamma r a ́ f-i$ & $($ na $)$ ráp $-s-i^{4}$ \\
\hline & 'S/he writes/is writing' & '(to) write' \\
\hline Past & $e ́-\gamma r a f-e$ & $\grave{e}-\gamma r a p-s-e$ \\
\hline & 'S/he was writing/used to write' & 'S/he wrote' \\
\hline
\end{tabular}

Table 1: Third person singular forms of the Greek verb yráfo 'write' showing the interaction of aspect with tense (adapted from HoLTON et al. 1997: 111)

Prépi na can be followed by all the forms given in Table 1 (as well as by the perfect and pluperfect). The resulting constructions and the modal values of the forms are given in Table 2.

\begin{tabular}{|c|c|c|}
\hline Non-past & $\begin{array}{l}\text { IMPERFECTIVE } \\
\text { prépi na yráfi } \\
\text { [+EVIDENTIAL -DEONTIC] }\end{array}$ & $\begin{array}{l}\text { PERFECTIVE } \\
\text { prépi na rrápsi } \\
\text { [-EVIDENTIAL+DEONTIC] }\end{array}$ \\
\hline Past & $\begin{array}{l}\text { prépi na érrafe } \\
\text { [+EVIDENTIAL-DEONTIC }\end{array}$ & $\begin{array}{l}\text { prépi na érrapse } \\
\text { [+EVIDENTIAL-DE }\end{array}$ \\
\hline
\end{tabular}

Table 2: Modal values of prépi na and combinations of tense and aspect

As can be seen in Table 2, there is a major split between an evidential and a deontic reading. When combined with past subordinates, prepi can only receive an evidential interpretation. ${ }^{5}$ When combined with the perfective non-past prepi is unambiguously deontic, whereas, when it is combined with the imperfective nonpast, prepi is normally evidential. ${ }^{6}$ This coarse-grained picture can be further refined if we take into account the actional class of the verb and the resulting interaction between action class, aspect, tense and mood. Since the past is always

\footnotetext{
${ }^{2}$ By contrast, the perfect and pluperfect - which are formed periphrastically with the auxiliary éxo 'have' - only combine with the perfective stem: éxo yráp-s-i (Perfect, lit. "I have written"), íxa yráp$s-i$ (Pluperfect, lit. "I had written").

${ }^{3}$ Stative verbs (such as BE, HAVE, KNOW, BELONG etc.) have only an imperfective stem.

${ }^{4} \mathrm{This}$ form is a dependent (or aorist subjunctive) form which cannot exist independently of a particle (such as the future particle tha, the subordinate marker $n a$ etc.) or certain conjunctions (cf. HOLTON et al. 1997: 110, 220ff.).

${ }^{5}$ In this case deontic modality is excluded. According to PALMER (1986: 97), deontic modality is future oriented, i.e. only the future or something in the future can be altered by one's actions. Therefore, prépi $n a+$ past can only assume an evidential interpretation.

${ }^{6}$ The modal values shown in Table 2 would plead for a core evidential meaning of prépi. Yet prépi occurs much more frequently with the perfective non-past. For example, in a sample of 2000 random hits from a 100 million corpus of Greek, only 57 examples $(2,85 \%)$ were evidential, all others showed the deontic use of prépi. Hence, the meaning of prépi cannot be specified independently of the constructions in which it occurs, as is argued for in this paper.
} 
evidential, we will only focus on the subtleties that emerge once the different action classes are contrasted in the non-past.

\subsection{Prépi na + states}

Stative verbs, most of which lack the forms of the perfective aspect (cf. note 3), can only receive an evidential interpretation. This holds true for the complete paradigm of the imperfective non-past.

(10)

O Jánis prépi na ine $\quad$ kurasménos /
DET John must COMP be-PRS:3SG tired /
éxi piretó.
have-PRS:3SG fever
'John must be tired/have a temperature.'

3.2. Prépi na + progressives

For the other action classes, the imperfective non-past is evidential if it can be interpreted as a progressive. This is the case in (11) with activities:

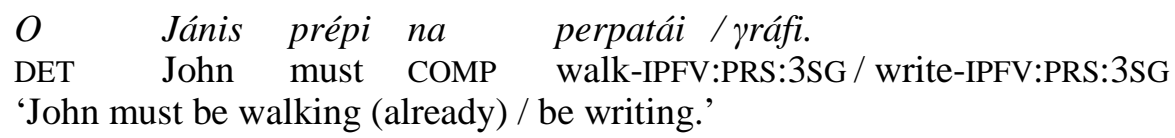

Similarly, with accomplishments, the imperfective form is evidential if it is interpreted as a progressive:

(12) To plío prépi na vïizete.

DET ship must COMP sink-IPFV:PRS:MPASS:3SG

'The ship must be sinking.'

$\begin{array}{llllll}O & \text { Jánis } & \text { prépi } & \text { na } & \text { majirévi } & \text { to fajitó. } \\ \text { DET } & \text { John } & \text { must } & \text { COMP } & \text { cook-IPFV:PRS:3SG } & \text { DETmeal }\end{array}$

'John must be cooking the meal.'

Finally, the imperfective non-past of achievements can only receive an evidential interpretation.

$\begin{array}{llll}\text { (14) } O & \text { Jánis prépi na peAéni. } \\ \text { DET John must } & \text { COMP } & \text { die-IPFV.PRS.3SG } \\ \text { 'John must be dying.' } & & \end{array}$

Thus, as was the case with DEVE in Italian (cf. 1.2), prépi can express evidentiality with non-stative predicates if the verb is in the imperfective non-past, which is interpreted as a progressive. 


\subsection{Prépi na + habituals}

Prépi na can also receive an evidential interpretation when it takes non-stative predicates that have an habitual meaning as complement. This is illustrated in examples (15) to (17) for activities, accomplishments and achievements respectively:

$\begin{array}{llll}\text { O Jánis prépi } & \text { na perpatái } & \text { káte méra } \\ \text { DET } & \text { John must } & \text { COMP walk-IPFV:PRS:3SG } & \text { every day } \\ \text { jatí } & \text { ine } & \text { se fórma }\end{array}$

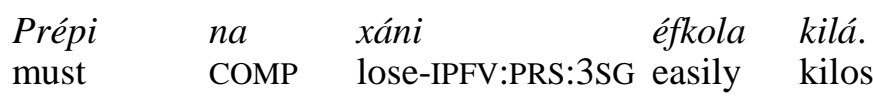

'(S)he must be losing weight easily.'

$\begin{array}{llll}\text { Prépi } & n a & \text { ksipnáil } & \text { févgi } \\ \text { must } & \text { COMP } & \text { wake up-IPFV:PRS:3SG/ leave-IPFV:PRS:3SG } \\ \text { norís } & \text { káae } & \text { proí. } \\ \text { early } & \text { every } & \text { morning }\end{array}$

'(S)he must wake up / leave very early every morning.'

\subsection{Prépi na + resultatives}

Prépi na is also interpreted as an evidential when it takes as complements nonstative predicates in the resultative aspect.
Prépi
na éxi perpatísil
éxi xonépsil
éxi fiji.
must COMP walk-PRF.3SG/ digest-PRF.3SG/ leave-PRF.3SG

'(S)he must have walked / have digested / have left.'

\section{Aspectual incompleteness}

The question arises how to describe and interpret this data. Is there a common feature to states, progressives, habituals and perfects? And why do evidential utterances select these aspectual values for their predicates?

As for the first question, it has been proposed by PIETRANDREA (2005) that states, progressives, habituals and resultatives do share a common aspectual feature in that none of them describes a change. Stative predicates do not describe changes by definition, since they indicate "inalienable qualities [...] of the subject, or states of affairs which are not modifiable without cancelling out the very existence of that

\footnotetext{
${ }^{7}$ Under an habitual interpretation, activities may be ambiguous between an evidential and a deontic interpretation, as is the case in (i). This ambiguity may arise because the activity is temporally limited.
} 
state of affairs" (BERTINETTO 1991: 30 - our translation). Progressives are variously interpreted in the literature: some authors regard progressives as framing an event with the effect of showing a dynamical fact statically (VLACH 1981, DOWTY 1986, LANGACKER 1987, 1991, PARSONS 1989). Other authors consider progressives as describing an ongoing process (COMRIE 1976, LEECH \& SVARTVIK 1981, BerTinetTo 1997, DesClÉS 1994, DEsClés \& GUENTCHEVA 1995): it marks the internal evolution of a change that has begun but is not accomplished. In the former case, progressives are reconducted to a particular type of states: dynamic states; in the latter cases, they are regarded as not describing the final state of a change. In any case, they do not describe changes. Habituals provide information about the regularity of a given event, without focalising the event as such and the change it causes. Resultative aspects do not focalise an event as such but the resulting state of an event. Their semantic characteristics can therefore be traced back to those of states.

If this analysis is correct, we can say that DEVE only receives an evidential interpretation when it takes infinitives not describing changes as complements, or, as PIETRANDREA (2005) puts it aspectually incomplete infinitives ${ }^{8}$. Quite similarly, prépi is an evidential marker under the same circumstances, i.e. when the verb in the following dependent clause does not describe changes and is thus aspectually incomplete.

\section{Aspectual incompleteness as a marker of propositionality}

As for the second question, it has been argued by PIETRANDREA (2005) that the reason why only aspectually incomplete infinitives licence the evidential interpretation of DEVE is to be found in the propositional nature of the elements in the scope of evidential modal auxiliaries.

As shown by BOYE (this volume), a defining feature for evidential markers is that they have scope over propositions rather than over States of Affairs (SoAs) ${ }^{9}$. Evidential markers do not modify the description of a SoA, rather they qualify the truth of the proposition conveying a given SoA, providing details on the source of evidence for asserting it.

The literature has shown that the distinction between propositions and descriptions of SoAs tends to be variously marked cross-linguistically. English distinguishes between propositional and non-propositional nominalisations (VENDLER 1967, BAEUERLE 1987) and between propositional and nonpropositional anaphoric operators (DIK 1997). Some languages distinguish between complementisers introducing a proposition and complementisers introducing the description of a SoA (FRAJZYNGIER 1995). In Spanish, as well as in Italian, the mood of explicit subordinates changes to mark the subordinate either as a propositional or as a non-propositional complement.

The linguistic relevance of this distinction is also proven by the differences shown by the complements of propositional - i.e. predicates selecting a

\footnotetext{
${ }^{8}$ PIETRANDREA (2005) borrows the term and the notion of aspectual incompleteness from LAZARD (2002).

9 As for the distinction between SoAs and proposition we refer, among others, to DIK (1997), HeNGeveld (1989), Boye (this volume).
} 
proposition as complement (predicate of propositional attitudes, predicates of propositional manipulation, predicates of knowledge, predicates of mental perception and predicate of saying; see DIK 1997: 106) and predicational predicates - i.e. predicates selecting the description of a SoA as complement (directive, volitional, phasal, achievement perception predicates; see DIK 1997: 110), at least in Italian. As shown by PIETRANDREA (2005: 161), when a complement of a propositional predicate is represented by an infinitive, this is characterised by aspectual incompleteness:

\section{STATES}

(19) So di essere felice / di avere 15 anni I know to be happy / to be fifteen

ACTIVITIES/ACCOMPLISHMENTS/ACHIEVEMENTS

(20) ?So di camminare / digerire / saltare I know to walk / digest / jump

\section{PROGRESSIVES/HABITUAL/RESULTATIVES}

(21) So di stare saltando / di saltare bene / di aver saltato I know I am jumping /I jump well / I have jumped

On the contrary, infinitive complements of predicational predicates can only be characterised by aspectual completeness:

\section{STATES}

(22) ?Vedo Luigi essere felice / avere 15 anni I see Luigi to be happy / to be fifteen

\section{ACTIVITIES/ACCOMPLISHMENTS/ACHIEVEMENTS}

(23) Vedo Luigi camminare / digerire / saltare I see Luigi (to) walk / digest / jump

\section{PROGRESSIVES/HABITUAL/RESULTATIVES}

(24) ?Vedo Luigi stare saltando / di saltare bene / di aver saltato I see Luigi (to) jumping /he jumps well / he has jumped

We refer to PIETRANDREA (2005: 177) for an account of this distribution. What matters here is that this distribution leads to an hypothesis that the reason why evidential modals take aspectually incomplete complements has to do with the fact that these complements indeed represent propositions rather than SoAs. 


\section{A constructional approach}

The regularities found in Italian and Greek lead us to claim that, in these languages, the evidential meaning is not conveyed by the two modals DEVE and prépi, but rather by the two constructions in (25) and (26):

(25) $\quad\left[\mathrm{DEVE}+\text { infinitive }_{\text {[-complete }]}\right]_{\text {<evidential }>}$

(26) $\left.[\text { prépi }+ \text { dependent verb (na-clause })_{[- \text {complete }]}\right]_{\text {<evidential }}$

Interestingly, the case of DEVE is not isolated. As shown by PIETRANDREA (2005), in fact, all the forms of modal auxiliaries taken as conveying evidentiality in Italian show the same constraints. As the examples from (27) through (29) show, the modal auxiliary DOVREBBE (i.e., the conditional form of the verb dovere roughly corresponding to 'should'), as well as the modal auxiliaries PUò and POTREBBE ('can' in its indicative and conditional forms, roughly corresponding to 'can' and 'could' respectively) can only be interpreted as evidential when they take as complements aspectually incomplete infinitives:

(27) Dovrebbe essere stanco $^{[+e v]} / /$ camminare $^{[- \text {ev }]} /$ digerire $^{[-\mathrm{ev}]} /$ saltare $^{[\text {-ev }] 10}$ 'He should [MUST.COND.3SG] be tired / / walk / digest / jump.'

(28) Può essere stanco ${ }^{[+e v]} / /$ camminare $^{[-\mathrm{ev}]} /$ digerire $^{[- \text {-ev }]} /$ saltare $^{[-\mathrm{ev}]}$ 'He can [CAN.IND.3SG] be tired / / walk / digest / jump.'

(29) Potrebbe essere stanco ${ }^{[+e v]} / /$ camminare $^{[-\mathrm{ev}]} /$ digerire $^{[-\mathrm{ev}]} /$ saltare $^{[-\mathrm{ev}]}$ 'He could [CAN.COND.3SG] be tired / / walk / digest / jump.' 11

These data suggest that a meso-construction - that is a set of similarly behaving constructions (TRAUGOTT 2007) - is associated in Italian with evidential meaning as such. This meso-construction is made up of a modal auxiliary followed by a [complete] infinitive, as represented in (30):

$$
\left[\text { MODAL AUXILIARY + infinitive }{ }_{[- \text {complete }]}\right]_{\text {<evidential }}
$$

The concrete lexical specification of the modal auxiliary defines the particular type of evidential meaning conveyed by the construction. Namely, [DEVE + infinitive $\left.e_{\text {-complete] }}\right]_{\text {<evidential }>}$, as mentioned above, may convey direct, inferential, or observational evidentiality; [DOVREBBE+ infinitive [-complete] $_{\text {<evidential }>}$ conveys either inferential or reportive evidentiality (PIETRANDREA 2005: 88); [PUO'+ infinitive I- $_{\text {- }}$ complete] $]_{\text {<evidential }}$ conveys in some contexts inferential evidentiality (PIETRANDREA 2005: 90); [POTREBBE + infinitive [-complete] $_{\text {<evidential }_{>} \text {may convey either inferential or }}$ reportive evidentiality.

\footnotetext{
${ }^{10}$ It should be noted that, as for DOVREBBE, aspectually complete infinitives do allow an evidential interpretation, but in this case the modalised proposition is not regarded as simultaneous with the speech process. In other words, complete infinitives impose a predictive interpretation of DOVREBBE (see PIETRANDREA 2005: 141 for details).

${ }^{11}$ See note 1 [???].
} 
In Greek as well, the same constraints that hold for an evidential interpretation of prépi also operate for the other forms of the modal auxiliaries, i.e. tha prépi (the conditional non-past of the verb 'must', roughly equivalent to 'should'), borí (3. person singular of 'can') and tha borúse (the conditional past of 'can', roughly equivalent to 'could'), which are all followed by a dependent clause introduced by $n a$. These modals can only receive an evidential interpretation when the verb in the dependent clause is in the imperfective or the perfect, i.e. if it is a [-complete] predicate. With states (cf. (31)), the evidential interpretation is the only option. In the case of activities, accomplishments, and achievements, the imperfective and perfect forms have an evidential interpretation (cf. (32) and (33) respectively) whereas the perfective forms in (34) have a deontic interpretation. In particular, the Greek forms can only convey (different types of) inferential evidentiality:

(31) Tha prépi/bori/tha borúse Should/can/could

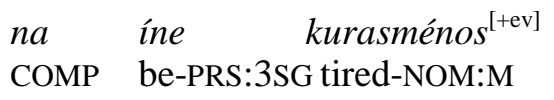
'He should/can/could be tired.'

(32) Tha prépi/borí/tha borúse Should/can/could xonévi ${ }^{[+\mathrm{ev}]}$ / digest-IPFV:PRS:3SG / leaving.'

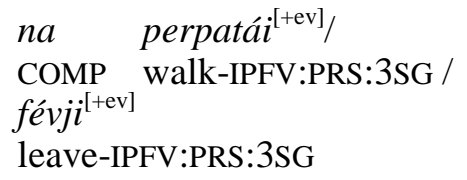

'S/he should/can/could have walked / have digested / have left.'

(34) Tha prépi/bori/tha borúse

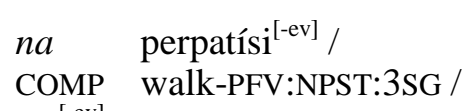

'S/he should/can/could walk/digest/leave.'

In analogy to (30) above, the corresponding meso-construction in (35) can be postulated for the Greek modal auxiliaries:

$$
\text { [MODAL AUXILIARY+ dependent verb (na-clause) } \left.)_{\text {[-complete }]}\right]_{\text {<evidential }}
$$

While the existence of a meso-construction associated with an evidential meaning may be of some theoretical interest to the understanding of the organisation of grammatical knowledge, this level of description is not to be taken into account in the structure of our database. The highly schematic meaning of meso-constructions indeed is not of practical interest, since it does not provide 
information on the particular type of evidentiality coded. We propose, therefore, to take the specified micro-constructions in (30) through (33) as a paradigm of evidential markers in Italian. Each of these micro-constructions would be treated as an entry of our database:

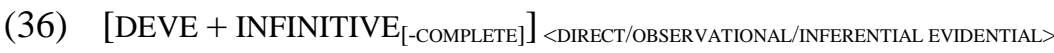

(37) [DOVREBBE + INFINITIVE $\left.{ }_{\text {[-COMPLETE }]}\right]$ 〈INFERENTIAL/REPORTIVE EVIDENTIAL〉

(38) [PUO' + INFINITIVE $\left.{ }_{\text {[-COMPLETE] }}\right]_{\langle\text {INFERENTIAL EVIDENTIAL }>}$

(39) [POTREBBE + INFINITIVE [-COMPLETE] $_{<_{\text {INFERENTIAL/REPORTIVE EVIDENTIAL> }}}$

Similarly for Greek, we propose to include the following micro-constructions in (40) to (43) as entries in the database:

(40) $[\text { prépi }+n a+\text { DEPENDENT VERB } \text { [-COMPLETE }]_{\text {[INFERENTIAL EVIDENTIAL }>}$

(41) $\left[\text { tha prépi }+n a+\text { DEPENDENT VERB }_{\text {[-COMPLETE] }}\right]_{\langle\text {INFERENTIAL EVIDENTIAL }}$

(42) $\left[\text { bori }+n a+\text { DEPENDENT VERB }_{\text {[-COMPLETE] }}\right]_{\text {〈INFERENTIAL EVIDENTIAL> }}$

(43) [tha borúse $+n a+$ DEPENDENT VERB $\left._{\text {[-COMPLETE] }}\right]_{\text {〈INFERENTIAL EVIDENTIAL〉 }}$

\section{Conclusion}

This article has shown that, at least in Greek and Italian, modal auxiliaries do not convey per se either deontic modality or evidentiality: they simply convey the notion inscribed in their lexical meaning, i.e. necessity (in the case of DOVERE and prepi) or possibility (in the case of possibility modals).

It is the entire construction made up of the modal and an aspectually specified subordinate that conveys either deontic modality or evidentiality. In particular, evidentiality is conveyed by the clustering of a modal auxiliary with an aspectually incomplete subordinate. Aspectually incomplete subordinates can indeed be read as atemporal propositions rather than concrete temporal SoAs. Since evidentiality only has semantic scope over propositions, the fact that the subordinate in the scope of a modal auxiliary can be read as a proposition is a necessary condition for the evidential reading of the entire construction.

We propose, therefore, to consider evidentiality as conveyed by complex constructions clustering a modal auxiliary and an aspectually incomplete subordinate and to take these constructions as entry of the database.

\section{References}

Bertinetto, Pier Marco (1991): Il verbo, in In RenZi, Lorenzo \& Giampaolo Salvi (eds), Grande grammatica italiana di consultazione, II. I sintagmi verbale, aggettivale, avverbiale. La subordinazione. Bologna: Il Mulino, 13-162.

BertinetTo, Pier Marco (1997): Il dominio tempo-aspettuale. Demarcazioni, intersezioni,contrasti. Turin: Rosenberg \& Sellier.

BOYE, KASPER (this volume). Evidentiality and scope.

COMrIE, BeRnARD (1976). Aspect. Cambridge: Cambridge University Press.

Clairis, Christos \& Babiniotis, Georgios (1999): Ghrammatikí tis Néas Ellinikís. Dhomoliturghikí

- Epikinoniakí. Vol. II. To Ríma. Athens: Elliniká Ghrámmata. [Modern Greek Grammar. Vol. II. The Verb] 
DESCLES, JEAN-PIERRE (1994). Quelques concepts relatifs au temps et à l'aspect pour l'analyse des textes, in Karolak, S., V. Koseska-Toszewa, J.- P. Descles \& Z. Guentcheva (eds.), Studia kognitywe Sémantique des catégories d'aspect et de temps [Études cognitives: Vol. 1. Semantyka kategorii aspecktu i czasu] Warsaw: Slawistyczny Os'rodek Wyd.57-88.

Descles, JeAn- Pierre \& ZlatKa GuentCheVa (1995): Is the Notion of Process Necessary?, in

Bertinetto, Pier Marco, Valentina Bianchi, James Higginbotham \& Mario SQuartini (eds). Temporal Reference Aspect and Actionality, I. Semantic and Synctactic Perspectives.Turin: Rosenberg \& Sellier. 55-70.

DiK, SIMON (1997): The Theory of Functional Grammar, I. The Structure of the Clause. (K. Hengeveld, ed). Berlin: Mouton de Gruyter.

DowTY, DAVID (1986):The Effect of Aspectual Classes on the Temporal Structure of Discourse: Semantics or Pragmatics?, in: Linguistic and Philosophy 9, 37-61.

HENGEVELD, KeES (1989): Layers and Operators in Functional Grammar. Journal of Linguistics 25,127-157.

Holton, David; Mackridge, Peter \& PhilipPaki-Warburton, Irene (1997): Greek: A Comprehensive Grammar of the Modern Language. London \& New York: Routledge.

LANGACKER, RONALD (1987): Nouns and Verbs, in:. Language 63.53-94.

LANGaCKer, Ronald (1991) Foundations of Cognitive Grammar, II. Descriptive Applications.

Stanford: Stanford University Press.

LAZARD, GILBERT (2002): Transitivity Revisited as an Example of a More Strict Approach

in Typological Research, in: Folia Linguistica 36:3-4.141-190.

LEECH GEOFREY \& SVARTVIK, JEAN (1981): A Communicative Grammar of English. London:

Longman.

PALMER, Frank Robert (1986): Mood and Modality. Oxford: Oxford University Press.

Parsons, Terence (1989): The Progressive in English: Events, States and Processes, in: Linguistics and Philosophy 12:2.213-241.

Pietrandrea, PaOla (2004): L'articolazione semantica del dominio epistemico dell'italiano, in: Lingue e Linguaggio 2.171-206

Pietrandrea, PaOla (2005): Epistemic modality. Functional Properties and the Italian System. Amsterdam: Benjamins.

SQUARTINI, MARIO (2004): Disentangling Evidentiality and Epistemic Modality in Romance, in: Lingua 114.873-895.

TRAUGOTt, ElizaBeTH Closs (2007): The concepts of constructional mismatch and type-shifting from the perspective of grammaticalization, in: Cognitive Linguistics 18, 523-557.

VeNDLER, ZeNo (1967) Linguistics in Philosophy. Ithaca: Cornell University Press.

Vlach, Frank (1981) Temporal Adverbs, Tenses and The Perfect. in Linguistics and Philosophy 16.231-283. 